\title{
Subirrigation equipment for the production of citrus rootstocks: Design and hydraulic assessment ${ }^{1}$
}

\section{Equipamento de subirrigação para produção de porta-enxertos de mudas cítricas: Projeto e avaliação hidráulica ${ }^{1}$}

\author{
Conan Ayade Salvador ${ }^{*}$; Roberto Testezlaf ${ }^{3}$; Carlos Vinícius Garcia Barreto ${ }^{4}$
}

\begin{abstract}
The aim of this study was to design and characterize hydraulic subirrigation equipment for the citrus rootstocks production of to allow the water capillary rise for the seedling stage. This equipment was designed since the citrus seedling phase occurs in plastic containers with substrate, and because there is a need to increase the irrigation efficiency in this sector. The methodology consisted of: (i) identification and characterization of the irrigation methods used in the citrus rootstocks production; (ii) the design of subirrigation equipment prototype; and, (iii) the construction and hydraulic evaluation of the prototype equipment. After a model was designed, 10 prototypes were built with two different dimensions (44 $\times 29 \times 15 \mathrm{~cm}$ and $62 \times 41 \times 15 \mathrm{~cm}$ ), and the theoretical and experimental relationships of flow and operating pressure were determined. The proposed equipment was designed according to engineering criteria that allows its evaluation for commercial use, although additional field trials are required for its final adjustment. Moreover, the theoretical equation of flow rate was validated for small-immersed orifices in thin walls, as an operational condition of the developed subirrigation equipment.
\end{abstract}

Key words: Citrus crop, capillary rise, containers, substrate, protected environment

\section{Resumo}

O objetivo deste trabalho foi projetar e caracterizar hidraulicamente um equipamento de subirrigação destinado à produção de porta-enxertos de mudas cítricas, na fase de sementeira, possibilitando a ascensão capilar da água. O projeto desse equipamento baseou-se no acondicionamento das mudas em tubetes com substrato e na necessidade de aumentar a eficiência da irrigação desse setor produtivo. O trabalho foi dividido nas seguintes fases: i) identificação e caracterização da operação de irrigação na produção de porta-enxertos cítricos; ii) projeto de um protótipo de equipamento de subirrigação; e, iii) construção e avaliação hidráulica do equipamento. Após a elaboração do projeto do equipamento, construiram-se 10 protótipos com duas diferentes dimensões ( 44 x 29 x $15 \mathrm{~cm}$ e 62 x 41 x $15 \mathrm{~cm}$ ), para os quais foram determinadas as curvas características teóricas e experimentais de vazão versus pressão de serviço. $\mathrm{O}$ equipamento proposto foi projetado dentro de critérios de engenharia que permitem o seu uso comercial, necessitando de ensaios de campo adicionais para a sua adequação final. Além disso, a equação teórica de determinação da vazão para orifícios afogados de pequenas dimensões e paredes delgadas foi validada para aplicação no dimensionamento do equipamento de subirrigação e na definição das suas condições operacionais.

Palavras-chave: Citricultura, ascensão capilar, tubetes, substrato, ambiente protegido

\footnotetext{
${ }^{1}$ Parte da Dissertação de Mestrado do primeiro autor apresentada ao curso de Pós-Graduação em Engenharia Agrícola, Universidade Estadual de Campinas, UNICAMP, Faculdade de Engenharia Agrícola, FEAGRI, Campinas, SP, Brasil.

2 Prof. Adjunto, Universidade Federal Rural do Rio de Janeiro, UFRRJ, Instituto de Tecnologia, Dept ${ }^{\circ}$ de Engenharia, Seropédica, RJ, Brasil. E-mail: conan@ufrrj.br

3 Prof. Titular, UNICAMP, FEAGRI, Campinas, SP, Brasil. E-mail: bob@feagri.unicamp.br

${ }^{4}$ Pesquisador, Instituto Nacional da Propriedade Industrial, INPI, Rio de Janeiro, RJ, Brasil. E-mail: cvbarreto@bol.com.br

* Author for correspondence
} 


\section{Introduction}

The citrus industry occupies a prominent position in Brazilian agribusiness, with a movement of $\$ 6.5$ billion for the $2009 / 2010$ harvest and total chain production revenue of $\$ 14.6$ billion (NEVES et al., 2011). This sector is responsible for a share of 230 thousand direct and indirect jobs, with an annual payroll of R\$676 million (GRIZOTTO et al., 2012). The State of São Paulo, plus the area corresponding to the Minas Gerais state triangle (citrus belt), currently represents about $80 \%$ of the national orange production (AGRIANUAL, 2014; FISCHER; ZANETTE, 2013). For the 2013/2014 harvest, the State of São Paulo has about 10 thousand citrus growers and an estimated production of 11 million tons of oranges, with a planted area of 501 thousand ha and 464.4 thousand ha in production (CONAB, 2013 ).

One of the key inputs for the formation of citrus orchards is the use of certified seedlings that have assured genetic and health qualities. In the State of São Paulo regulations governing the mandatory production of seedlings in protected environments (NORMAS PARA PRODUÇÃO DE MUDAS CERTIFICADAS DE CITROS, 1998) have been in force since 1998. However, the current legislation does not regulate the operation of water-nutrient management in the production of seedling rootstocks, which is performed in most nurseries by manually operated irrigation sprinkler systems (SALVADOR, 2010). These systems apply excessive amounts of water and, combined with the leaf interception as the plant grows (umbrella effect), leads to the irregular distribution of water, thus reducing irrigation efficiency. This method also increases the risk of environmental pollution due to the disposal of residual solution from fertigation (SCHMAL et al., 2011; FERRAREZI et al., 2012). It is estimated that between $49 \%$ and $83 \%$ of water applied through canopy irrigation is lost in the process and fails to reach the inside of the containers (DUMROESE; DAVIS; JACOBS, 2011).
In most cases, the waste water from this production system, ends up in the soil, and can cause salinization and contamination of groundwater and generate losses of supplies (FERRAREZI et al., 2013; MANGIAFICO et al., 2010). Additionally, according to Teixeira et al. (2009), in the specific case of citrus rootstock cultivation in containers or trays, wetting the aerial part of the plant can facilitate the establishment of water-borne fungal and bacterial diseases.

The subirrigation method, by which water moves vertically by capillary rise in the substrate until it reaches the root system of plants, and can operate in an open or closed system, can potentially be used in crop production in protected environments, enabling a reduction of environmental and financial costs through resource conservation (SCHMAL et al., 2011). In addition, several studies (ANDRIOLO; BOEMO; BONINI, 2001; GENEVE; KESTER; BUXTON, 2004; DUMROESE et al., 2006; MONTESANO; PARENTE; SANTAMARIA, 2010; FERRAREZI; VAN IERSEL, 2011; MELLANO, 2011; FERRAREZI et al., 2013; MELO JUNIOR; GERVÁSIO; ARMINDO, 2013) have shown that subirrigation systems provide a more uniform and efficient application of solution, eliminating water and nutrient loss. These systems are made possible by automation and recirculation of the nutrient solution, and lead to increased production with better uniformity across the unit area, as well as reduced growth time.

Subirrigation systems can be used to produce different cultivars, as in the case of forest seedlings, ornamental plants, fruit trees, and palms. Dumroese, Davis, and Jacobs (2011) studied the growth of koa seedlings (Acacia koa A. Gray) in 50-656-mL containers, with fertilization rates $\left(0-9.6 \mathrm{~kg} \mathrm{~m}^{-3}\right)$ and found that the use of a subirrigation system compared with canopy irrigation, resulted in higher irrigation efficiency and fertilizer use, although the vigor of the seedlings was similar in both systems. Pinto, Chandler and Dumroese (2008) confirmed that subirrigation of 'Pale' Echinacea 
seedlings resulted in increased seedling height and biomass quality, improved nitrogen use efficiency, and lower mortality, when compared to sprinkler irrigation. Montesano, Parente and Santamaria (2010) studied the cultivation of cherry tomatoes under saline conditions, using continuous closed cycle subirrigation and traditional drip systems, and obtained similar results with both in terms of yield and quality, however, subirrigation had a lower environmental impact.

In the application of subirrigation for citrus seedling growth, Ferrarezi et al. (2013) studied the control of subirrigation with moisture sensing capacitors in containers of Rangpur lime in pine bark substrate, and optimized the management of volumetric water content, which when combined with $50 \%$ level of the recommended fertilizer, reduced the production time when compared with the conventional system. Giuliani et al. (2014) found that the height of the container influenced the emergence and development of six rootstocks during subirrigation (Trifoliate, Flying Dragon, Fepagro C37 citrange, Volkameriano lemon, Sunki tangerine, and Swingle citrumelo), showing the superiority of $120 \mathrm{~cm}^{3}$ alveoli cultivation trays in each cell compared to conical plastic tubes with a volume of 50 or $120 \mathrm{~cm}^{3}$.

Despite the potential demonstrated by subirrigation, its implementation in production systems is virtually nonexistent in Brazil (RIBEIRO; FERRAREZI; TESTEZLAF, 2014). As a result, the equipment currently in operation was developed for specific applications and was made by hand because of a lack of a commercial technological alternative. Aiming to contribute to the use of subirrigation by capillarity in the production of citrus rootstock seedlings, the objective of this study was to design and evaluate hydraulic equipment to use for subirrigation of rootstocks of citrus seedlings in the seed stage, and to define the basic operating conditions for their use.

\section{Material and Methods}

The research was conducted at the Laboratory of Hydraulics and Irrigation, College of Agricultural Engineering (CAE), University of Campinas (UNICAMP). The study was divided into the following steps:(i)identification and characterization of the irrigation method in the production of citrus rootstocks; (ii) design a prototype of subirrigation equipment; (iii) construction and hydraulic assessment of the equipment.

Seeking to identify the specific operating conditions of irrigation employed in rootstocks production and to find possible technological innovations for the activity, technical visits were conducted to several companies involved in the production of citrus trees. After evaluating operating systems for this type of production, different conceptual proposals for the subirrigation equipment were prepared, considering criteria such as cost, phytosanitary security, seedling development, simplicity, flexibility of operation, and type of material. From the practical understanding of the capillarity rise principle, and the operational characteristics of the equipment proposed and the technical simplicity of construction and operation, a prototype of simple construction requiring easy operation was selected.

Aiming to obtain optimal specifications for the operating equipment, the hydraulic characterization of prototypes was performed by determining the relationship between flow rate and working pressure for two sizes of modules, and two internal diameters of water inlet, 4 and $7 \mathrm{~mm}$, were chosen according to the commercial availability of water supply hoses for the equipment.

Trails were performed at three operating pressures, 10, 15, and $20 \mathrm{kPa}$, under two equipment operating conditions, which were the in the presence and absence of substrate-filled containers. These experimental conditions were defined to characterize the intrinsic operation of the device itself and, subsequently, to compare the effect of 
the presence of substrate within the container at the time of equipment wetting. The test pressure range was chosen based on the possibility of evaluating increased flow rate due to elevated pressure $(5 \mathrm{kPa}$ increments), and the limitation on the maximum hydraulic head provided by the test module reservoir, which had adjustable height at the water inlet of the subirrigation equipment.

Figure 1 shows the experimental module built for laboratory tests. This consisted of: (A) a structure with two brackets for positioning the prototype; (B) a table, for controlling the operation of the water inlet; (C) a reservoir with a constant water level and adjustable height to provide different supply pressures; (D) a piezometer for controlling the pressure supplied to the system; and (E) a drainage system comprising a reservoir and a hose for draining water.

Figure 1. Diagram of the experimental module used for the hydraulic characterization of the equipment: Legend: A. Support of the modules to be tested hydraulically; B. Operation control table of water entering the module; C. Adjustable height reservoir and constant water level; D. Piezometer; E. Drainage system.

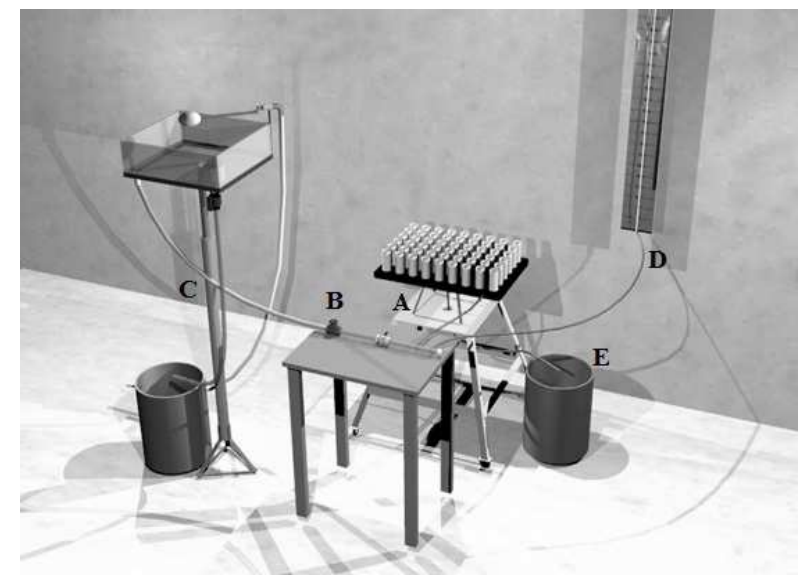

Source: Elaboration of the authors.

Trails were performed to determine the water filling time of the prototype for the three selected working pressures $(10,15$, and $20 \mathrm{kPa})$, with three replicates for each prototype designed, setting the maximum level that water should reach inside the PVC tubes, which accommodated containers (production cells) placed $12 \mathrm{~cm}$ from the base of the tubes. This level was set to prevent the overflow of water from production cells during subirrigation, indicating the end of the filling operation within the chambers.

After filling the equipment, the drainage process was held with the entire effluent collection by the drainage reservoir, to quantify the fill volume of the prototype and the flow rate of the system to the working pressure measured in each assay. The water volume collected in the drainage was quantified by determining its mass $(\mathrm{kg})$, using a PSP 500 Sipebras scale with a $2.5 \mathrm{~kg}$ (minimum) to $500 \mathrm{~kg}$ (maximum) load, calibrated to the nearest $0.1 \mathrm{~kg}$ to ensure the reliability of results obtained. The drainage reservoir and drained water volume were then weighed together, subtracting from the total volume the average mass of the empty reservoir. The drained volume $\left(\mathrm{m}^{3}\right)$ was calculated by dividing the water mass $(\mathrm{kg})$ by the water density $\left(\mathrm{kg} \mathrm{m}^{-3}\right)$, monitoring water temperature during all tests performed.

The collected data were validated by the theoretical equation of flow depending on the 
working pressure of small-immersed orifices with thin walls (AZEVEDO NETTO et al., 1998), Equation 1.

$$
Q=C_{Q} \cdot A \cdot \sqrt{2 g\left(h_{0}-h_{1}\right)} .
$$

wherein:

$\mathrm{Q}$ - volumetric flow, $\mathrm{m}^{3} \mathrm{~s}^{-1}$;

$\mathrm{C}_{\mathrm{Q}}$ - discharge coefficient (considered to be equal to 0.61 );

$\mathrm{A}$ - intake orifice area, $\mathrm{m}^{2}$;

$\mathrm{g}$ - acceleration of gravity, $\mathrm{m} \mathrm{s}^{-2}$;

$\mathrm{h}_{0}$ - water column height above the center of gravity of the opening at the water surface in the supply reservoir, $\mathrm{m}$; and,

$\mathrm{h}_{1}$ - water column height above the center of gravity of the opening at the water surface inside the tube, m.

In the validation of Equation 1, the values of A, $\mathrm{C}_{\mathrm{Q}}$, and $\mathrm{g}$ were considered constant and were 0.125 $\mathrm{cm}^{2}$ (4 mm nozzle) and $0.385 \mathrm{~cm}^{2}$ (7 mm nozzle), respectively; 0.61 (recommended by AZEVEDO NETTO et al., 1998); and $9.81 \mathrm{~ms}^{-2}$, which were pooled and referred to as the proportionality coefficient characteristic of the orifice $(\mathrm{K})$. Thus, the determination of the relationship between flow rate $(\mathrm{Q})$ and pressure $(\mathrm{P})$ was performed using Equation 2, as suggested by Keller and Karmeli (1975) to describe the characteristics of flow rate versus emitter pressure (in this case, the water flow nozzle).

$$
\mathrm{Q}=\mathrm{K} \mathrm{P}^{\mathrm{X}}(2)
$$

wherein:

$\mathrm{x}-$ is the kinetic coefficient of runoff water.

As the study of immersed orifices adjusted to the working pressure is defined by the difference of hydraulic loads $\left(\mathrm{h}_{0}\right.$ and $\left.\mathrm{h}_{1}\right)$, we replaced $\mathrm{P}$ by $\mathrm{P}$ ' in Equation 2, where $\mathrm{P}$ ' is equivalent to this difference. The value of $h_{0}$ is equal to the pressure applied to each test, and $h_{1}$ at the height of water entering the inlet nozzle in the prototype, which was maintained constant at $13.5 \mathrm{~cm}$ in the hydraulic tests. Thus, the equations for the equipment evaluated were statistically adjusted.

In the assessment of the hydraulic behavior of the prototype in presence of substrate filled containers, conical tubes were used, with superior external and internal diameters equal to 4.8 and 3.7 $\mathrm{cm}$, respectively; equivalent to $1.2 \mathrm{~cm}$ internal basal diameter; a total height of $13.7 \mathrm{~cm}$; with an internal volume of $1.0 \times 10^{-4} \mathrm{~m}^{3}$. Filling tubes with substrate was carried out by a self-compression method, as suggested by Pire and Pereira (2003) and Barreto, Testezlaf and Salvador (2012), adapted for holding four beats of container with heights proportional to 1.5 times the superior internal diameter on a flat and rigid surface. The commercial substrate selected to fill the tubes was ground pine bark with fine texture, enriched with nutrients with the following composition: $70 \%$ pine bark, $25 \%$ vermiculite, $5 \%$ sand, mean moisture content of $62 \%$ (volume basis) and an uncompressed density equal to $300 \mathrm{~kg} \mathrm{~m}^{3}$.

In tests to determine the relationship between flow rate and working pressure in the presence of substrates, it was necessary to differentiate the first repetition of prototype wetting, as the initial moisture conditions of substrate density could generate differential hydraulic behavior in the remaining repetitions. Under this test condition, when the maximum water level was reached inside the tubes, we waited $15 \mathrm{~min}$ to facilitate the absorption of the water and ensure the complete saturation of the substrate. System drainage was then carried out by collecting all the effluent by reservoir drainage, thus allowing quantification of the filling volume and the flow rate for the evaluated pressure, as occurred in trials without substrate filled tubes.

\section{Results and Discussion}

\section{Criteria for the design of equipment}

The systematic production of citrus seedling rootstocks observed during technical visits 
demonstrated the predominant use of countertop production, with tubes attached to wire mesh or rigid plastic trays. Thus, seeking to reduce the impact of significant technological changes in the production system, we chose to design a modular prototype in the form of subirrigation trays. This model allowed the connection of portable modules through delivery lines with plastic hoses to provide a water supply, enabling the assembly of production stands according to the manufacturer's instructions, thus ensuring mounting flexibility and simplicity in operation installations and maintenance of the subirrigation system.

According to the literature, the movable trays are characterized by allowing zero percolation (considering a closed system) and mechanical transport, since they can serve as a growth medium and transport between greenhouses, and allows the use of $81 \%$ to $89 \%$ of the available production space (UVA et al., 2000). However, these devices have limited commercial significance, due to deployment and maintenance costs, in addition to the lack of technical expertise needed to train farmers to use commercial applications (UVA et al., 2000; RIBEIRO; FERRAREZI; TESTEZLAF, 2014).

Thus, the proposed equipment should meet the following design criteria: grouping of tubes in modules with characteristics similar to trays to support the rootstocks already used by the producer; individual cameras for housing tubes; and water pouring and distribution in pipes with small diameters, which could be designed according to the procedure defined by Bernardo, Soares and Mantovani (2005).

Another benefit we sought by the development of the system into modules with a fixed number of rootstocks, was to ensure the health of seedlings treated by the subirrigation equipment, if contamination by phytopathogens occurs in a given subirrigation module, only the seedlings inserted on it would be susceptible to contamination, and therefore discarded. Thus, this type of system designed in modules would ensure sanity was maintained in other equipment on the same bench. Nevertheless research studies show a lower incidence and severity of water-borne diseases in subirrigation when compared to conventional irrigation systems (STANGHELLINI et al., 2000; ROEBER, 2010).

\section{Project and construction of the equipment prototype}

The proposed subirrigation tray consists of a chamber of water at the base, built with $3 \mathrm{~cm}$ high acrylic resin and fiberglass; a structure for housing tubes made of PVC pipes of $4 \mathrm{~cm}$ outside diameter and $12.5 \mathrm{~cm}$ long. A closing fast-type spherical valve was inserted at the center bottom of the water chamber, allowing the drainage of the water absorbed during the irrigation. Ten trays were built, five smaller $(44 \times 29 \times 15 \mathrm{~cm})$ with an internal volume of $11 \mathrm{~L}$, and five larger $(62 \times 41 \times 15 \mathrm{~cm})$ with an internal volume of $12 \mathrm{~L}$. Both dimensions were designed for 54 seedling production cells (Figures 2 and 3).

The construction of trays with two different dimensions was due to the need to increase the available space for seedlings during the vegetative growth period after the initial stage of rootstocks development, thus minimizing competition for resources such as solar radiation. This adjustment, recommended by nurserymen, requires greater spacing between production cells to reduce competition between plants and enable greater vegetative development.

Additionally, in the proposal we sought a tray design that was easy to build and operate, since preliminary tests showed a perfect water-tight seal between the connected parts and the lightness of the set, providing practical system installation and maintenance. 
Figure 2. Prototype details of capillary subirrigation, smaller tray with the water chamber composed of acrylic resin and PVC support structure to the tube. Side view (A) and top view (B).
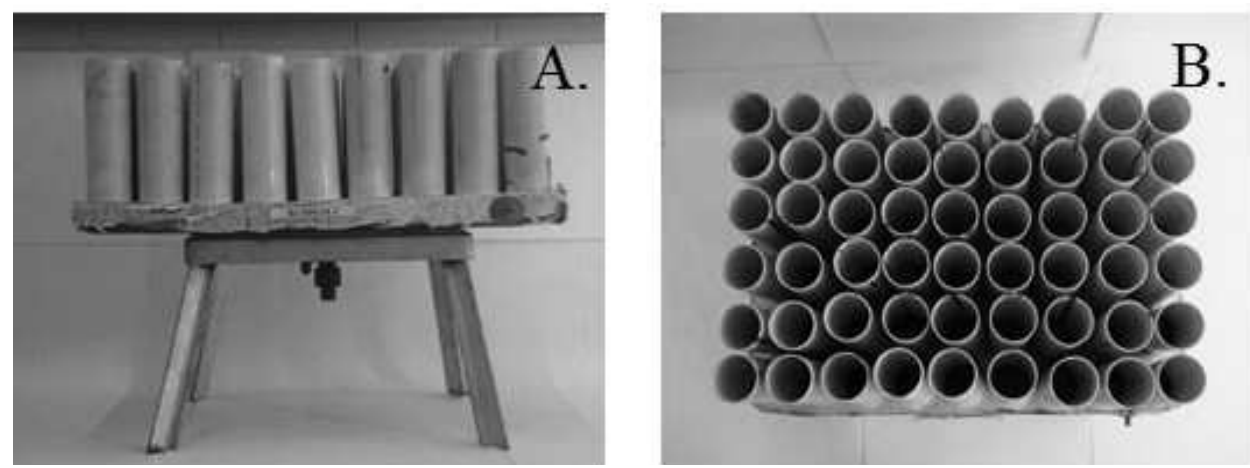

Source: Elaboration of the authors.

Figure 3. Prototype details of capillary subirrigation, larger tray with water chamber in acrylic resin and PVC support structure to the tube. Side view (A) and top view (B).

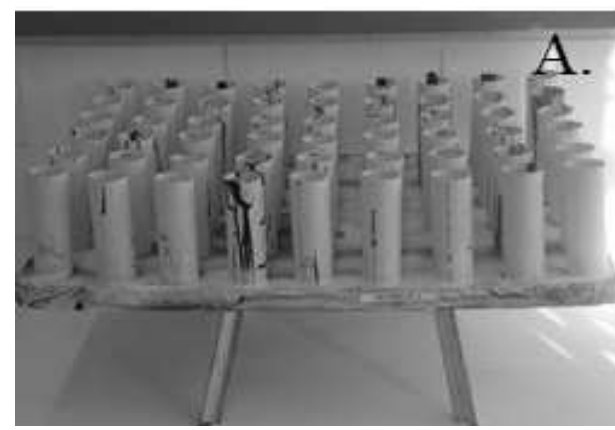

Source: Elaboration of the authors.

The material chosen had a limitation since resin contracts during its drying process, causing a small convex curvature of the water chamber, generating a small bend in the base of the prototype. Moreover, the acrylic resin that was selected had some fragility in laboratory tests, ease of rupture during its handling in transportation, installation, operation and maintenance activities, as well as the release of toxic gases due to their handling during the fabrication process. Despite repeated attempts in association with private companies to construct this prototype using plastic material, this option was ruled out due to lack of specific machines for manufacture molds. However, these problems did not hamper the use of this prototype for the

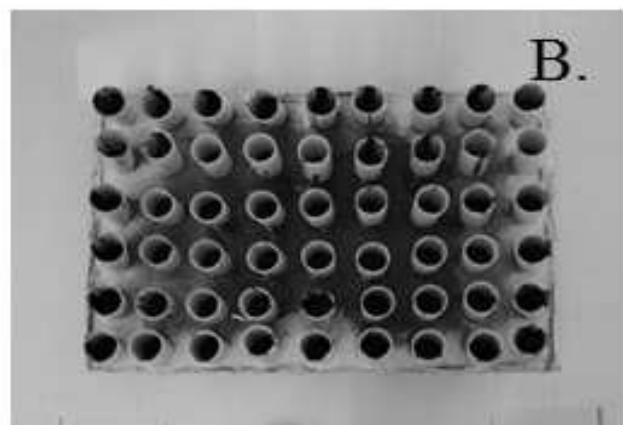

subirrigation capillarity equipment proposed in this study.

\section{Characterization of hydraulic equipment}

Variation of flow rates according to the working pressure for the two dimensions of subirrigation trays $(44 \times 29 \times 15 \mathrm{~cm}$ and $62 \times 41 \times 15 \mathrm{~cm})$, obtained from tests with, and without the presence of substrate containing tubes, for water inlet diameters of 4 to $7 \mathrm{~mm}$, are shown respectively in Figures 4 and 5 . In addition, these graphs were plotted with curves of the calculated theoretical flow equation obtained for small-immersed orifices with a thin wall, Equation 1. 
Figure 4. Characteristic flow rate curves versus pressure for trays of major and minor dimensions, obtained from tests without and with tubes filled with substrate, to the inner diameter of the water inlet of $0.004 \mathrm{~m}$.

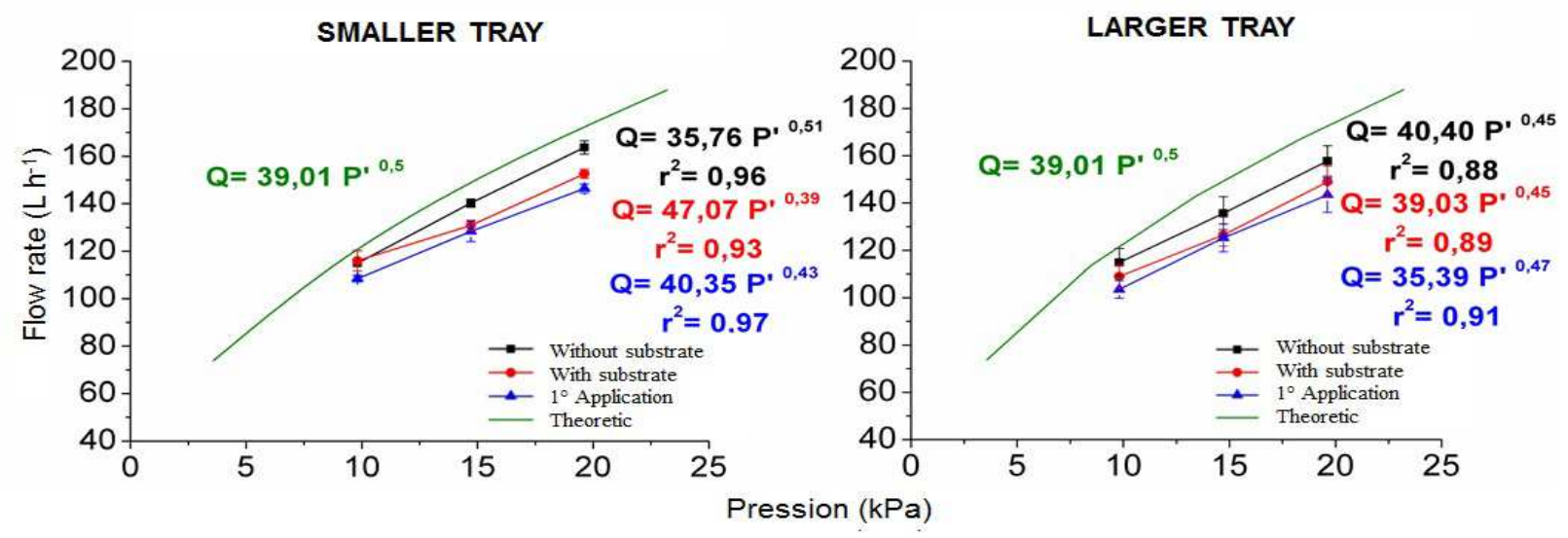

Source: Elaboration of the authors.

Figure 5. Characteristic flow rate curves versus pressure for trays of major and minor dimensions, obtained from tests without and with tubes filled with substrate, to the inner diameter of the water inlet of $0.007 \mathrm{~m}$.

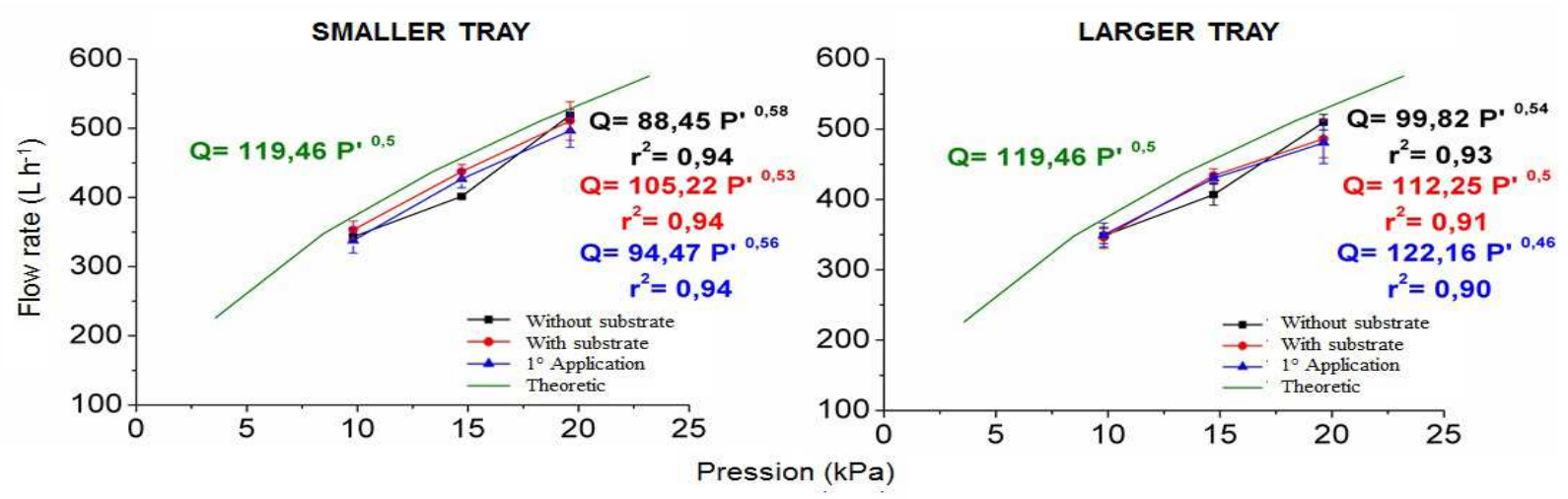

Source: Elaboration of the authors.

Comparing the maximum average flow rates achieved in different sized trays for different water supply diameters, it was found that the tray with the inner diameter for water entry of $4 \mathrm{~mm}$ had a maximum flow rate of $163.73 \mathrm{~L} \mathrm{~h}^{-1}$ for an operating pressure of $20 \mathrm{kPa}$ in the test without substrate. Conversely, the tray with an internal diameter of 7 mm obtained a maximum flow rate of $510.58 \mathrm{~L} \mathrm{~h}^{-1}$ under the same operating pressure $(20 \mathrm{kPa})$, with substrate filled tubes. The flow increase was due to the increase in nozzle water entrance, since these magnitudes are directly proportional.
Figure 4 shows the comparison between pairs of flow rate versus operating pressure for tests with and without substrate. The results show that smaller and larger trays with a $4 \mathrm{~mm}$ inlet diameter and substrate filled tubes, exhibited reduced flow rate, except under conditions of $10 \mathrm{kPa}$ working pressure. However, when pressure was increased, the velocity increase was augmented and thus the flow rate did not change since the area for water entrance remained the same. For the larger tray, the flow difference between the two test conditions remained practically constant with increasing pressure. 
Moreover, when analyzing the effect of the substrate filled tubes for the two tray dimensions with the larger inlet diameter $(7 \mathrm{~mm})$, no effect of water resistance was observed during the drainage operation (Figure 5).

In tests using substrate filled tubes, for trays with inlet diameters of different sizes, we found lower values of flow rate for the first application, when compared with the results of the other repetitions, this being a more noticeable effect for the lowest inlet diameter. This occurred because in the first application the substrate had moisture provided by the manufacturer (around 62\%), and in the subsequent applications, after the saturation and drainage process, the moisture was close to the capacity of the container, increasing substrate hydraulic conductivity, providing less water resistance when entering containers and increasing the input flow. This result is similar to that observed in soils where the hydraulic conductivity is higher in wet than in dry condition (CARON and ELRICK, 2005).

In all equations, high coefficients of determination $\left(r^{2}\right)$ were observed, confirming the good representation of the adjusted models. It was observed in these equations (Figures 4 and 5), that the proportionality coefficient increased as the tray water supply orifice diameter increased, while the kinetic coefficient varied from 0.39 to 0.58 , allowing full operation during a predominantly turbulent flow regime, where the flow rate is proportional to the pressure square root (DANTAS NETO et al., 1997). According to Frizzone et al. (2012), turbulent emitting flow $(x=0.5)$ produced about $10 \%$ of flow variation for a variation in pressure of $20 \%$. The variability found between trays can be attributed to their dimensional differences, caused by the differential hardening of the acrylic resin during the manufacturing process.

The structural conditions tested showed that the curve is near the characteristic theoretical curve of the test without the presence of substrate filled tubes, which demonstrates the feasibility of its use in determining the flow rate of the irrigation equipment. Thus, the possibility of applying this type of equation for sizing the flow of capillarity subirrigation systems, similar to those developed in this study was shown.

These results demonstrate that capillary subirrigation trays with different dimensions have a similar function in the study of flow rate versus pressure. In this case, there are only operational differences in the use of the two trays regarding irrigation time, since they have different maximum volumes.

\section{Conclusions}

The developed capillary subirrigation equipment allowed adequate conditions of water supply, presenting a unique functional characteristic to systems that perform subsurface irrigation, with potential for use on a commercial scale. However, we emphasize the need for additional field tests confirm its suitability for subsequent commercial application.

The hydraulic characterization of the developed prototype allowed us to validate a theoretical equation to determine the flow rate of smallimmersed orifices and thin walls for application in the design of similar subirrigation equipment for citrus rootstocks production.

\section{Acknowledgements}

To FEAGRI/UNICAMP, the Environment and Irrigation Technology Research Group, to CNPq and Capes, for the research support and incentives.

\section{References}

ANDRIOLO, J. L.; BOEMO, M. P.; BONINI, J. V. Crescimento e desenvolvimento de mudas de tomateiro e melão empregando os métodos de irrigação por microaspersão, inundação subsuperficial e flutuação. Horticultura Brasileira, Brasília, v. 19, n. 3, p. 200-203, 2001. 
ANUÁRIO DA AGRICULTURA BRASILEIRA AGRIANUAL. Citros: laranja, limão e tangerina. São Paulo: Ed. FNP Consultoria e Comércio, 2014.

AZEVEDO NETTO, J. M.; FERNANDEZ Y FERNANDEZ, M.; ARAÚJO, R.; ITO, A. E. Manual de hidráulica. 8. ed. São Paulo: Ed. Edgard Blucher, 1998. $670 \mathrm{p}$.

BERNARDO, S.; SOARES, A. A.; MANTOVANI, E. C. Manual de irrigação. Viçosa: Ed. UFV, 2005. v. 7, 611 p.

BARRETO, C. V. G.; TESTEZLAF, R.; SALVADOR, C. A. Ascensão capilar de água em substratos de coco e de pinus. Bragantia, Campinas, v. 71, n. 3, p. 385-393, 2012.

CARON, J.; ELRICK D. E. Measuring the unsaturated hydraulic conductivity of growing media with a tension disc. Soil Science Society of America Journal, Madison, v. 69, n. 1, p. 783-793, 2005.

COMPANHIA NACIONAL DE ABASTECIMENTO CONAB. Acompanhamento da safra brasileira: laranja safra 2013/2014, terceiro levantamento. Brasília: CONAB, 2013. $11 \mathrm{p}$.

DANTAS NETO, J.; MEDEIROS, M. G. A.; AZEVEDO, C. A. V.; AZEVEDO, H. M. Performance hidráulica e perfil de distribuição de água no microaspersor NAAN 7110, sob diferentes condições de vento. Revista Brasileira de Engenharia Agrícola e Ambiental, Campina Grande, v. 1, n. 1, p. 57-67, 1997.

DUMROESE, R. K.; DAVIS, A. S.; JACOBS, D. F. Nursery response of acacia koa seedlings to container size, irrigation method, and fertilization rate. Journal of Plant Nutrition, New York, v. 34, n. 1, p. 877-887, 2011.

DUMROESE, R. K.; PINTO, J. R.; JACOBS, D. F.; DAVIS, A. S.; HORIUCHI, B. Subirrigation reduces water use, nitrogen loss, and moss growth in a container nursery. Native Plants Journal, Madison, v. 7, n. 3, p. 253-261, 2006.

FERRAREZI, R. S.; RIBEIRO, M. D.; VAN IERSEL, M. W.; TESTEZLAF, R. Subirrigation controlled by capacitance sensors for citrus rootstock production. American Society for Horticultural Science, Alexandria, v. 48, n. 9, 2013. Supplement 3.

FERRAREZI, R. S.; SANTOS, L. N. S.; SOUZA, A. C. M.; PEREIRA, F. F. S.; ELAIUY, M. L. C.; TORREL, U.; MATSURA, E. E. Altura da lamina, tempo e volume de enchimento de um equipamento de irrigação por pavio e determinação da uniformidade de distribuição de água em substrates. Bragantia, Campinas, v. 71, n. 2, p. 273281, 2012.
FERRAREZI, R. S.; VAN IERSEL, M. W. Monitoring and controlling subirrigation with soil moisture sensors: a case study with hibiscus. Proceedings of SNA Research Conference, Water Management Section, Tennessee, v. 56, n. 1, p. 187-191, 2011.

FISCHER, I. H.; ZANETTE, M. M. Injúrias em laranja 'Valência' produzida em sistemas orgânico e convencional. Semina: Ciências Agrárias, Londrina, v. 34, n. 6, 2013. Suplemento 1.

FRIZZONE, J. A.; FREITAS, P. S. L.; REZENDE, R.; FARIA, M. A. Microirrigação: gotejamento e microaspersão. Maringá: Editora da Universidade Estadual de Maringá, 2012. 356 p.

GENEVE, R. L.; KESTER, S. T.; BUXTON, J. W. Capillary mats alter the waqter content in medium during mist propagation of dendranthema. American Society for Horticultural Science, Alexandria, v. 39, n. 3, p. 584-587, 2004.

GIULIANI, J. C.; RIETH, S.; SOARES, W.; LOUROSA, G.; SOUZA, P. V. Substratos e recipientes para a produção de porta-enxertos de citros irrigados por subcapilaridade. Ciência Rural, Santa Maria, v. 44, n. 3, p. 446-452, 2014.

GRIZOTTO, R. K.; SILVA, J. A. A.; MIGUEL, F. B.; MODESTO, R. T.; VIEIRA JUNIOR, J. B. Qualidade de frutos de laranjeira Valência cultivado sob sistema tecnificado. Revista Brasileira de Engenharia Agrícola e Ambiental, Campina Grande, v. 16, n. 7, p. 784-789, 2012.

KELLER, J.; KARMELI, D. Trickle irrigation desing. Glendora: Rain Bird splinkles manu-faturing corp. 1975. $133 \mathrm{p}$.

MANGIAFICO, S. S.; NEWMAN, J.; MOCHIZUKI, M.; ZURAWSKI, D.; MERHAUT, D. J.; FABER, B. Nurseries surveyed in Southern California adopt best practices for water quality. California Agriculture, Berkeley, v. 64, n. 1, p. 26-30, 2010.

MELLANO, V. J. Runoff \& nonpoint source pollution self-assessment. University of california cooperative extension condado de São Diego. San Diego: Greenhouses \& container nurseries, 2011. Disponível em: $<\mathrm{http}: / /$ cesandiego.ucdavis.edu/files/8455.pdf $>$. Acesso em: 24 jun. 2014.

MELO JUNIOR, J. C. F.; GERVÁSIO, E. S.; ARMINDO, R. A. Sistema de automação para o manejo de subirrigação em ambiente protegido. Irriga, Botucatu, v. 18, n. 2 , p. $337-350,2013$.

MONTESANO, F.; PARENTE, A.; SANTAMARIA, P. Closed cycle subirrigation with low concentration 
nutrient solution can be used for soilless tomato production in saline conditions. Scientia Horticulturae, Amsterdam, v. 124, n. 3, p. 338-344. 2010.

NEVES, M. F.; TROMBIN, V. G.; MILAN, P.; LOPES, F. F.; CRESSONI, F.; KALAKI, R. O retrato da citricultura brasileira. São Paulo: CitrusBR, 2011. 138 p.

NORMAS PARA PRODUÇÃO DE MUDA CERTIFICADA DE CITROS. Laranja, Cordeirópolis, v. 19, n. 2, p. 411-421, 1998.

PINTO, J. R.; CHANDLER, R. A.; DUMROESE, R. K. Growth, nitrogen use efficiency, and leachate comparison of subirrigated and overhead irrigated pale purple coneflower seedlings. American Society for Horticultural Science, Alexandria, v. 43, n. 3, p. 897-901, 2008.

PIRE, R.; PEREIRA, A. Propriedades físicas de componentes de substrato de uso común en la horticultura del estado de Lara, Venezuela: propuesta metodológica. Bioagro, Barquisimeto, v. 15, n. 1, p. 55-64, 2003.

RIBEIRO, M. D.; FERRAREZI, R. S.; TESTEZLAF, R. Assessment of subirrigation performance in eucalyptus seedling production. HortTechnology, Alexandria, v. 24, n. 2, p. 231-237, 2014.

ROEBER, R. U. Environmentally sound plant production by means of soilless cultivation. Comunicata Scientiae, Bom Jesus, v. 1, n. 1, p. 1-8, 2010.
SALVADOR, C. A. Sistema de irrigação por capilaridade na produção de porta-enxerto de mudas cítricas na fase de sementeira. 2010. Dissertação (Mestrado em Engenharia Agrícola) - Faculdade de Engenharia Agrícola, Universidade Estadual de Campinas, Campinas.

SCHMAL, J. L.; DUMROESE, R. K.; DAVIS, A. S.; PINTO, J. R.; JACOBS, D. F. Subirrigation for production of native plants in nurseries - concepts, current knowledge, and implementation. Native Plants Journal, Madison, v. 12, n. 2, p. 81-93, 2011.

STANGHELLINI, M. E.; NIELSEN, C. J.; KIM, D. H.; RASMUSSEN, S. L.; RORBAUGH, P. A. Influence of sub-versus top-irrigation and surfactants in a recirculating system on disease incidence caused by Phytophthora spp. in potted pepper plants. Plant Disease, Saint Paul, v. 84, n. 10, p. 1147-1150, 2000.

TEIXEIRA, P. T. L.; SHÄFER, G.; SOUZA, P. V. D. de; TODESCHINI, A. Desenvolvimento vegetative de portaenxertos de citros produzidos em diferentes recipientes. Ciência Rural, Santa Maria, v. 39, n. 6, p. 1695-1700, 2009.

UVA, W. F. L.; WEILER, T. C.; MILLIGAN, R. A.; ALBRIGHT, L. D.; HAITH, D. A. Risk analysis of adopting zero runoff subirrigation systems in greenhouse operations: a Monte Carlo simulation approach. Agricultural and Resource Economics Review, New York, v. 29, n. 1, p. 229-239, 2000. 
